\title{
Professional Development Activities of IELTS Trainers from Non-English Major
}

\author{
Nur Setyo Wulandari ${ }^{*}$, Bambang Yudi Cahyono², Niamika El Khoiri ${ }^{3}$ \\ 1,2,3 Department of English, Faculty of Letters, Universitas Negeri Malang, East Java, Indonesia \\ *Corresponding author: nswln03@gmail.com
}

\begin{abstract}
Professional development activities are done by English teachers from formal educational institutions and by trainers from non-English majors who teach IELTS preparation program in non-formal educational institutions. This study investigated the professional development activities done by IELTS trainers from non-English majors and how the professional development activities help them improve their teaching competencies. A case study design was applied, and an in-depth interview and documentary analysis were used to gain the data. Four selected research subjects were involved in this study. The results showed that the IELTS trainers' professional development activities include collaborative and independent learning activities. Furthermore, those activities help the IELTS trainers from non-English majors positively as they can fulfill their demand to improve their teaching competencies since there is limited institutional support for them in professional development. Therefore, the institution where the IELTS trainers work should provide adequate formal learning supports. In addition, the IELTS trainers in this study and other IELTS trainers should be involved in other informal learning activities more frequently.
\end{abstract}

Keywords: Autonomous Learners, Collaborative Learning, IELTS

$\begin{array}{lll}\text { History: } & & \text { Publisher: Undiksha Press } \\ \text { Received } & \text { : 2 January } 2021 & \text { Licensed: This work is licensed under } \\ \text { Revised } & \text { : 25 January } 2021 & \text { a Creative Commons Attribution 3.0 License } \\ \text { Accepted } & : \text { 26 March } 2021 & \end{array}$

\section{Introduction}

One of the roles of a teacher as an educator, especially in English as a Foreign Language (EFL), is to help students learn and achieve their target language (Liton, 2012; Litz, 2005). Thus, the quality of the teacher should become a priority in the area of professional development. This is because students' learning is affected by the quality of the teacher, which is proven as the most influential factor besides materials, resources, and the curriculum. In other words, it can be said that the higher the quality of the teacher, the better the result of the students' learning. Therefore, improving the quality of the English teacher is a demanding task to develop the teacher's professionalism which gives more contribution to the success of the students' learning outcome of the target language (Irmawati et al., 2017; Sari et al., 2019). Therefore, several authors' notions of teacher's professional development have been addressed (Atay, 2008; Vo \& Nguyen, 2020).

Professional development is an ongoing and lifelong learning phase of the teachers (Atay, 2008). It is a kind of teachers' effort to improve their teaching quality to guide their learning optimally. Professional development is conducted at both pre-service and in-service levels. Professional development deals with exchanging professional ideas, learning from each other, and helping each other to develop (Vo \& Nguyen, 2020). Further explanation of professional development is given by Avalos (2011), who stated that professional 
development is about teachers learning, learning how to learn, and transforming their knowledge into practice for the benefit of their students' growth. Irmawati et al. (2017) stated that a professional development activity should be an effective means contributing to the teachers' teaching practice and the better learners' learning outcome.

Several studies dealing with professional development activities done by the teachers have been conducted. Priajana (2017) showed that the teachers conducted three main professional development themes, namely self-initiated professional development, institutional, professional development, and non-institutional professional development activities. Another study was conducted by Irmawati et al. (2017) shows that reform types of activities are dominant for structural features of professional development in which the activities were conducted as needed; thus, the duration could not be counted precisely. The core features of professional development activities were mainly in the form of discussion which allowed the teachers to do some reflection as well as take and give suggestions. While there have been a lot of studies on professional development activities conducted by school teachers, there has been limited information about the professional development activities conducted by IELTS trainers who come from non-English majors. Therefore, further investigation is needed to explore the professional development activities conducted by IELTS trainers in the non-formal context of English language teaching.

Teaching IELTS may differ from teaching general English (Baghaei et al., 2020; Dashti \& Razmjoo, 2020). Since the IELTS test is a high-stakes test, it gives both trainers and test-takers some pressure during the preparation. The test takers may force themselves to perform their best during the test to obtain a high score. This condition encourages the IELTS trainers to give the best training to their IELTS students. It is then interesting to find out the activities conducted by IELTS trainers, particularly those from non-English majors and those who try to develop their professionalism to deal with the students' demand to achieve a high score. Furthermore, professional development is necessary to be done by the IELTS trainers since they are from non-English majors. By developing their professionalism, teachers can improve their knowledge and skills (Anto \& Coenders, 2019). Teachers' knowledge includes declarative knowledge, which deals with anything about English, and procedural knowledge, which refers to skills related to processing, procedures, and strategies that help teachers perform a particular task in their teaching practice (Irmawati et al., 2017). Thus, their competencies and quality will develop so that they contribute more to the IELTS students' learning outcome in preparing their official IELTS test.

The professional development programs, particularly for IELTS trainers, are not as frequently conducted as formal teachers. IELTS trainers lack the opportunity to engage in professional development activities since there is a lack of explicit content or training for them (Chalhoub-Deville \& Turner, 2000; Estaji \& Ghiasvand, 2019). Nevertheless, it is still possible for the IELTS trainers to improve their professionalism by utilizing independent learning activities. Masouleh \& Jooneghani (2012) stated that independent learning has a similar concept with 'autonomous learning in language education.' 'learner independence,' and 'self-direction.'

Independent learning can also be defined as an activity in skill development and knowledge acquirement outside formal training (Ellingson \& Noe., 2017). This kind of learning activity can be in the form of collaboration, observation, exploration, daily practice, and reflection. Kitsantas \& Dabbagh (2012) stated that independent learning could also be in the form of "observation, trial, and error, asking for help, conversing with others, listening to stories, reflecting on a day's events, or stimulation by general interests." In addition, learning by using technological tools such as e-learning, mobile learning, and online learning can be done in the teachers' autonomous learning program. Therefore, it can be said that although there is a lack of formal training programs, IELTS trainers can carry out professional 
development activities through autonomous learning programs. The IELTS trainers were adaptive to the condition in their institution and decided to intensify their independent learning. To be "adaptive" in response to the available condition is a fundamental characteristic of teachers in today's era of technological development (Seng et al., 2020).

Compared to the previous findings from other researchers, the point that makes the present study different focuses on investigating the professional development activities of IELTS trainers from non-English majors who teach IELTS preparation classes. Thus, it has filled the gap of the previous studies that focus on English teachers' professional development activities from English majors, and they teach in formal educational institutions (Anugerahwati \& Saukah, 2010; Irmawati et al., 2017; Priajana, 2017; Vo \& Nguyen, 2020). Therefore, this study aimed at investigating the professional development activities of IELTS trainers from non-English majors. In addition, it also aimed at examining how the professional development activities undertaken by the IELTS trainers help them develop their teaching competencies.

\section{Materials and Methods}

This research was a case study conducted to generate data in natural conditions by interviewing the research subjects and observing the everyday activities of the research subjects in the IELTS preparation classes. It also explores more about the research subjects by scrutinizing their portfolios. A preliminary study was conducted in two courses which provide IELTS preparation classes in Kampung Inggris (English Village) at Pare of Kediri Regency, East Java; to select the subjects based on the criteria of qualified IELTS trainers designed in this study, namely the IELTS trainers' teaching competences (personal, social, pedagogical, professional competences). Moreover, their IELTS score which is determined to be at the "seven" band. This band refers to the average score of four language skills measured in the IELTS test, namely listening, speaking, reading, and writing.

After the subjects were selected, we started to collect data by asking permission to conduct interviews. A semi-structured interview guide was used to collect data related to the kinds of professional development activities that have been done by the research subjects and how the activities help them develop their teaching competencies. Furthermore, we also examined relevant documents, including the IELTS trainers' certificates, teaching records, and practice notes. Four subjects were selected as they met the criteria and willing to participate in this study. The subjects were four female IELTS trainers from various nonEnglish majors, as shown in Table 1.

Table 1. The Subjects' Profile

\begin{tabular}{cccc}
\hline Subjects & Gender & $\begin{array}{c}\text { IELTS } \\
\text { band score }\end{array}$ & $\begin{array}{c}\text { Academic } \\
\text { qualification }\end{array}$ \\
\hline T1 & Female & 8.0 & Bachelor of Pharmacy \\
T2 & Female & 7.0 & Bachelor of Nutrition \\
T3 & Female & 7.5 & Bachelor of Pharmacy \\
T4 & Female & 7.0 & Bachelor of Mathematics \\
\hline
\end{tabular}

As shown in Table 1, the minimum band of the IELTS scores of the research subjects was 7 as achieved by two subjects (T and T4). The highest band, 8.0, was achieved by T1, while the other subject (T3) achieved 7.5 band. Two subjects (T1 and T3) were from Pharmacy major, and each of the other two subjects was from Nutrition (T2) and Mathematics (T4) majors. 


\section{Results and Discussion \\ Results}

There are two significant findings of the present study, and these findings conform to the study's objectives. The first finding showed that IELTS trainers from non-English majors had done several professional development activities during their teaching career. The professional development activities which the IELTS trainers from non-English majors have done are presented in Table 2.

Table 2. Professional Development Activities which IELTS trainers from non-English Majors do

\begin{tabular}{lc}
\hline No. Professional Development Activities & Category of informal learning \\
\hline 1. Discussing with the colleagues and the expert & Collaborative \\
2. Making use of the internet & Independent \\
3. Reading relevant sources & Independent \\
4. Reflecting on self-experiences & Independent \\
5. Observing other trainers' class activities and taking & Collaborative \\
6. Practicing & Independent \\
\hline
\end{tabular}

Table 2 shows the professional development activities of the IELTS trainers both in collaborative and independent learning categories. The collaborative activities include "having a discussion with colleagues and expert" and "observing other trainee's class." The other activities are different kinds of independent learning activities. These activities include "making use of the Internet," "reading relevant sources," "reflecting on self-experiences," "observing other trainers" class and taking notes," and "practicing."

The second finding justifies how the professional development activities conducted by the IELTS trainers help them develop their teaching competencies which cover four aspects of competencies: personal, social, pedagogical, and professional competencies. Table 3 shows the aspects of competencies that could be developed due to the professional development activities.

Table 3. Aspects of Competences Which Developed as a Result of Professional Development Activities done by IELTS trainers from non-English Majors

\begin{tabular}{llcccc}
\hline \multirow{2}{*}{ No } & \multirow{2}{*}{ Professional Development Activities } & \multicolumn{4}{c}{ Aspects of Competences } \\
\cline { 3 - 5 } & Dersonal & Social & Pedagogical & Professional \\
\hline 1. & $\begin{array}{l}\text { Discussing with the colleagues and } \\
\text { the expert }\end{array}$ & $\sqrt{ }$ & $\sqrt{ }$ & $\sqrt{ }$ \\
2. & Making use of the internet & - & - & $\sqrt{ }$ & $\sqrt{ }$ \\
3. & Reading relevant sources & - & - & $\sqrt{ }$ & $\sqrt{ }$ \\
4. & Reflecting on self-experiences & $\sqrt{ }$ & $\sqrt{ }$ & $\sqrt{ }$ & - \\
5. & Observing other trainers' class and & - & - & $\sqrt{ }$ & - \\
6. & Practe-taking & & & $\sqrt{ }$ \\
\hline
\end{tabular}

\section{Discussion}

Professional Development Activities of IELTS Trainers from Non-English Majors

The findings of the study showed that the IELTS trainers were from non-English majors. As IELTS trainers, they are demanded to be competent in the subject matter, particularly language skills, including listening, speaking, reading, and writing. However, the interview revealed no specific formal training program for them to be engaged in, particularly 
from the institution in which they work. They were not alone in facing this shortage of institutional support. The providers of English courses do not provide teaching training for their workers of IELTS test preparation class (Chowdhury, 2009; Tuyen, 2015). Thus, informal learning activities are the alternative ways to develop the research subjects' teaching competence, mostly done without institutional sponsorship. Therefore, the research subjects are categorized into autonomous learners who used non-institutional sources to develop their competence. They conduct professional development activities voluntarily, and the objective of their action is not planned, but it occurs due to their ongoing awareness of the need and value of learning (Ellingson \& Noe., 2017). The IELTS trainers have been very "adaptive" to the need to be teachers in the twenty-first century (Seng et al., 2020).

The first professional development activity is having discussions with colleagues and experts. All of the subjects agreed that this is the most frequent activity to develop their teaching competence. This activity is categorized as informal collaborative in which the discussions are usually in the form of the study group. T2 and T3 said the time and duration could not be predicted since the activity is done whenever the trainers face the problems or difficulties they face during their teaching practices. Group discussion was done in the workplace, and it involved more than one participant. T4 added that she sometimes conducted the discussion at home through WhatsApp since it is only between her and her supervisor. Furthermore, the expert's involvement, in this case, the supervisor, also contributes to broadening the trainers' knowledge to deal with the problem-solving matter in their teaching practice.

The subjects explained that in the study group, they usually discussed their problem related to their readiness to handle the various sizes of classroom students, build a classroom atmosphere, and show their confidence during the teaching practice as part of their personal competence development. In addition, they also discussed issues related to social aspects of their teaching competence, particularly communication skills. In terms of pedagogical competence, discussing with the colleagues and the expert is to learn how to select and prepare the materials for the IELTS students, how to select and implement the appropriate technique based on IELTS students' level and condition, and how to give an evaluation for the student's learning outcome. Furthermore, conducting some discussions also help the research subjects develop their understanding of the IELTS material and its implementation, which belong to their professional aspect of teaching competence. This is in line with Vo \& Nguyen's (2020) statement that sharing the knowledge through discussion in which the trainers can give and take is one factor in improving the trainers' teaching competence.

Professional development activity dealing with making use of the internet is classified as independent learning. The four research subjects agreed that using the internet supports their pedagogical skill in teaching IELTS. The internet provides the trainers' source of information, knowledge, and a community with diverse experiences, which allows the research subjects to gain new insight into ideas and issues related to their teaching career. They can find many sources, particularly for their task in giving appropriate assignments for the IELTS learners. The research subjects stated that by using the internet, they adapt the available material as the assignment for the students. Besides, the trainers said that the use of the internet is flexible since they can access it anytime and anywhere as long as they have a good internet connection. In terms of the professional aspect, they think that using the internet gives them a source of knowledge that helps them improve their understanding of IELTS material. Priajana (2017) reported that online activity supports the teachers to be active contributors and participants who direct and construct the learning events for the group and create regular opportunities for enhancing the learning-teaching context.

The following professional development activity is reading references related to the IELTS. This activity has been done mainly for pedagogical and professional competencies 
development. All research subjects stated that reading some references contributes to their idea's development in preparing and choosing the IELTS materials. The references are primarily from printed books or e-book, which they got from the other trainers or their supervisor. In comparison, Murray (2010) said that the apparent sources are from journals related to English teaching. Additionally, T1 and T4 said that this activity also helps them give the students an assignment. They argued that by reading the references they have, they could develop the type of assignment appropriate to the students' level. Besides, by reading the references, the trainers get a fundamental theory which they did not get during their training, and it develops their performance in their teaching practice because they can share it with their students. Concerning this, it shows that the research subjects tend to read the appropriate sources to their need and interest (Simegn, 2014). To summarize, conducting reading activities keeps the trainers up-to-date with novel ideas and themes (Priajana, 2017).

The next activity which the IELTS trainers do is making use of their experiences. This activity is categorized as independent learning (Ahmadi et al., 2019; Jones \& Dexter, 2014). More particularly, the trainers utilized their experiences both in their pre-service education when they learned IELTS and in their in-service IELTS teaching. By combining pre-service and in-service experiences, the trainers can give appropriate teaching applications for their IELTS learners since they get insights into both students' and teachers' sides. This point is relevant with Ahmadi et al. (2019) statement that reflecting self-experiences is a part of understanding others that is relevant to the teacher's role who applied interpersonal relationship in their teaching practice. All research subjects agreed that their experiences are essential points in their IELTS teaching career, which is varied for each of them, notably how they adjusted themselves in various class sizes. T1 said that she used her experiences during her IELTS preparation program that she undertook. Since she is not from English education major, she was not studying how to teach and handle students in the class; studying IELTS gives her insight during her teaching IELTS practice. Unlike T2 and T3, they argued that although they are from nutritionist and pharmacy majors, their experiences in giving counseling in various kinds and numbers of audiences become the perception in handling the classroom. T4 said that in her experience as a lecturer assistant, she was obliged to handle the audience in big numbers to cope with the situation in the class, such as building the atmosphere. They also common to build communication aspect since they were already familiar with the situation.

Different from the other three trainers, T1 said that she also conducted classroom observation of her colleagues. It happened in her first teaching period when she was still confused about coping with the classroom situation with the numbers of audiences. She argued that this kind of activity contributes to her teaching practice to arrange some ideas in handling the class in the various numbers of students. In addition, by observing other classes taught by different teachers, she could also learn some strategies to engage the students during the learning process. Engaging students is an important step to lead the students to mastery of the lesson (Yulia et al., 2020).

Another professional development activity is practicing, which all research subjects have done. They realize that practice is an essential thing for their teaching career since they are not English majors, so that they undertake this activity to improve their skill in handling the classroom, creating a joyful atmosphere for the students, and improving their confidence. Moreover, this activity is done anytime during their teaching practice. They also said that it could be done in pairs, particularly in practicing to build the atmosphere, such as making jokes or games. They will practice it with their colleagues before they applied it in the classroom.

Looking at the discussion related kinds of professional development activities conducted by the IELTS trainers, they have a favorable view about the crucial effect of 
professional development on their teaching career. By doing those kinds of activities, the trainers believe that they can apply appropriate and suitable teaching practices for their IELTS students and provide some support to help them achieve their goals. Concerning the importance of professional development activity, some experts supported this topic with their findings (Anugerahwati \& Saukah, 2010; Irmawati et al., 2017; Priajana, 2017). They argue that various types of professional activities which teachers undergo help them improve their teaching skills.

With the research subjects' awareness of conducting professional development activity, the positive perspective of conducting those actions is one of their motives (Irmawati et al., 2017). As IELTS trainers from non-English majors, the research subjects realize that they need to improve their teaching competencies since the background of their study was far from the IELTS teaching activity. Thus, these trainers see that their informal learning activities as a crucial and continuous way which they are through to achieve that improvement. As a crucial process in their IELTS teaching journey, professional development activities support the trainers to perform professional teaching of IELTS. Moreover, the notion of continuous professional development activities to the findings of this research can be reported as the effort of the research subjects to develop their teaching competence through many kinds of informal learning activities during their pre-service until in-service teaching experiences. This is in line with what is stated by Priajana (2017) and Irmawati et al. (2017) that teacher's quality improvement can be made through many kinds of ways that are done continuously.

\section{How Professional Development Activities Help Develop IELTS Trainers' Competences}

Based on the in-depth interview with the four research subjects, in terms of personal competence, their informal activities enable them to control their emotion in conducting and handling the class. As a result, they are also more confident and able to solve the problems in teaching. Furthermore, the activities also help the research subjects to conduct good communication with their IELTS students as both trainers and friends, showing that the social aspect as a trainer is developed. Concerning the pedagogical aspect, it is clear that the findings show the trainers' positive perceptions related to the kind of informal activities which they have been through. Furthermore, these activities help them improve their skills in material preparation and application of IELTS. Since their bachelor degree does not support them with that matter, and their pre-service experiences are only limited to understanding the materials, conducting the informal development activities limits the gap of this case. Lastly, informal professional development activities develop the IELTS trainers' professional competence through collaborative and independent learning to gain a good understanding of the subject matter.

A study by Masouleh \& Jooneghani (2012) stated that as autonomous learners, the trainers might be aware of their learning styles and strategies to work on their weaknesses using their strengths. Concerning the research subjects' status as autonomous learners, this form of learning is the only way for them since there is less support from the institution in which they work in. For the IELTS trainers, their awareness of their needs in developing their skills leads them to this learning mode. Referring to independent learning, in which the IELTS trainers become self-motivated to improve their skill, it is essential to relate this with Self-Determination Theory. The notion that the subjects of this study have done several kinds of professional development activities that lead them to become autonomous learners has supported the self-determination theory. This can be seen from the activities done during their professional development activities, categorized into informal activities both collaboratively and independently. 
Informal learning type is divided into two kinds of the learning process, namely collaborative and independent learning. Collaborative learning accommodates the research subjects with the give-and-take knowledge and ideas among their colleagues. Referring to this learning model that research subjects have done, the collaboration of IELTS trainers in learning activity might be related to the social learning theory reflected in the activities that have been done during their professional development activity (Irmawati et al., 2017; Priajana, 2017). Another mode, which is independent learning, assists the trainers with broadening information where they can find new insight, ideas, and knowledge, particularly as Internet users. Together, both colleagues-related learning and independent learning simultaneously support the research subjects to improve their teaching competencies. This supports the finding of Jones \& Dexter (2014), which reported that these modes of professional development activities supported each other in powerful ways, which are essential and valuable for a different kind of situation in the learning process.

\section{Conclusion}

The present study has revealed that the IELTS trainers from non-English majors conducted various informal professional development activities regardless of the shortage of institutional support. These informal professional development activities could be categorized into collaborative and independent learning. The study has also revealed that the informal professional development activities that the IELTS trainers conducted led them to achieve various aspects of teaching competencies: personal, social, pedagogical, and professional competencies. To sum up, referring to the findings and the discussion, it can be said that IELTS trainers, as the subjects of this research, are categorized as autonomous learners in the effort of developing their teaching competencies to support their IELTS teaching career. Since there is a lack of formal learning support from the institution and their awareness to develop their competence as IELTS trainers, various kinds of informal learning become the solution which the research subjects undertake as professional development activities. Furthermore, the findings also imply that although the research subjects' background is not related to English education, they can be IELTS trainers.

\section{References}

Ahmadi, S., Riasati, M. J., \& Bavali, M. (2019). A Comparison of Writing Performance of Iranian IELTS Candidates Facing Chart Topics vs. Table Topics in Academic Writing (Task 1). International Journal of Instruction, 12(4), 17-34. https://doi.org/10.1080/2331186X.2019.1640655.

Anto, A. G., \& Coenders, F. (2019). Teacher learning in collaborative professional development: Changes in teacher and student practices. In J. Pieters, J. Voogt, \& N. P. Roblin (Eds.), Collaborative curriculum design for sustainable innovation and teacher learning.

Anugerahwati, M., \& Saukah, A. (2010). Professional competence of English teachers in Indonesia: A profile of exemplary teachers. Indonesian Journal of English Language Teaching, 6(2), 47-59. https://doi.org/10.25170/ijelt.v6i2.1545.

Atay, D. (2008). Teacher research for professional development. ELT Journal, 62(2), 139147. https://doi.org/10.1093/elt/cc1053.

Avalos, B. (2011). Teacher professional development in teaching and teacher education over ten years. Teaching and Teacher Education, 27(1), 10-20. https://doi.org/10.1016/j.tate.2010.08.007.

Baghaei, S., Bagheri, M. S., \& Yamini, M. (2020). Analysis of IELTS and TOEFL reading and listening tests in terms of revised bloom's taxonomy. Cogent Education, 7(1). 
https://doi.org/10.1080/2331186X.2020.1720939.

Chalhoub-Deville, M., \& Turner, C. E. (2000). What to look for in ESL admission tests: Cambridge certificate exams, IELTS, and TOEFL. System, 28(4), 523-539. https://doi.org/https://doi.org/10.1016/S0346-251X(00)00036-1.

Chowdhury, S. A. (2009). Gaining proficiency in the reading module in IELTS: A study on the efforts of Bangladeshi students. Dhaka University Journal of Linguistics, 2(3), 125-140. https://doi.org/10.3329/duj1.v2i3.4148.

Dashti, L., \& Razmjoo, S. A. (2020). An examination of IELTS candidates' performances at different band scores of the speaking test: A quantitative and qualitative analysis. Cogent Education, 7(1). https://doi.org/10.1080/2331186X.2020.1770936.

Ellingson, J. E. R., \& Noe., R. (2017). Autonomous learning in the workplace. Routledge.

Estaji, M., \& Ghiasvand, F. (2019). The Washback Effect of IELTS Examination on EFL Teachers' Perceived Sense of Professional Identity: Does IELTS Related Experience Make a Difference? Journal of Modern Research in English Language Studies, 6(3), 103. https://doi.org/10.30479/jmrels.2019.11123.1391.

Irmawati, D. I., Widiati, U., \& Cahyono, B. Y. (2017). How do Indonesian professional English teachers develop their pedagogical competence in teaching implementation? Arab World English Journal, 8(2), 293-307. https://doi.org/10.24093/awej/ vol8no2.21.

Jones, W. M., \& Dexter, S. (2014). How teachers learn: the roles of formal, informal, and independent learning. University of Virginia.

Kitsantas, A., \& Dabbagh, N. (2012). Personal learning environment social media and selfregulated learning: A natural formula for connecting formal and informal learning. Internet Higher Education, 15(1), 3-8. https://doi.org/10.1016/j.iheduc.2011.06.002.

Liton, A. (2012). Developing EFL Teaching And Learning Practices In Saudi Colleges: A Review. International Journal of Instruction, 5(2), 129-152.

Litz, D. (2005). Text Book Evaluation and ELT Management: a South Korea Case Study. Asian EFL Journal. https://docslide.us/documents/litz-thesis.html.

Masouleh, N. S., \& Jooneghani, R. B. (2012). Autonomous learning: A teacher-less learning. Procedia-Social and Behavioral Sciences, 55, 835-842. https://doi.org/10.1016/j.sbspro.2012.09.570.

Murray, A. (2010). Empowering teachers through professional development. English Teaching Forum, 48(1), 2-11. https://eric.ed.gov/?id=EJ914883.

Priajana, N. (2017). Self and group initiated professional development pursuits of EFL teachers. Indonesian Journal of English Education, 4(1), 31-48. https://doi.org/10.15408/ijee.v4i1.6597.

Sari, D. F., Fitriani, S. S., \& Emafetery, S. (2019). The strategy of Two Stay Two Stray to improve EFL students' reading skill. Studies in English Language and Education, 6(1), 171-184. https://doi.org/10.24815/siele.v6i1.13057.

Seng, G. H., Muhamad, M., \& Kiely, R. (2020). Integration of 21st century skills and teacher characteristics in ESL classrooms: The case of Malaysia. Universal Journal of Educational Research, 8(12), 7561-7566.

Simegn, B. (2014). EFL teachers' self-initiated professional development: Perceptions and Practices. Academic Journals, 9(21), 1109-1114. ttps://eric.ed.gov/?id=EJ1045576.

Tuyen, L. (2015). An Investigation into the Use of the Course Book for Non-English Major 
Students at the Tertiary Level. International Journal on Studies in English Language and Literature, 3(6), 14-30.

Vo, L. T., \& Nguyen, H. T. M. (2020). Critical friends group for EFL professional development. ELT Journal, 64(2), 205-213. https://doi.org/10.1093/elt/ccp025.

Yulia, M. F., Sulistyo, G. H., \& Cahyono, B. Y. (2020). Affective engagement in academic reading: What EFL student teachers reveal. International Journal of Evaluation and Research in Education (IJERE), 9(3), 781-798. https://files.eric.ed.gov/fulltext/EJ1274719.pdf. 